Andreas Albertsen

\title{
Lader held-egalitarismen fanden tage de uansvarlige sidste?
}

Held-egalitarismen er en indflydelsesrig teori om fordelingsmæssig retfærdighed, der indebærer, at fordelinger er retfærdige, når og kun når menneskers relative positioner afspejler deres udøvelse af ansvar. Denne teoriretning kritiseres ofte for ikke at kunne retfærdiggøre hjælp til dem, der grundet deres egne valg ender i en situation, hvor basale behov ikke opfyldes. Kritikkens styrke er kun tilsyneladende, fordi det er muligt både at forhindre, at nogen falder under et behovsminimum, og undgå at give køb på grundlæggende held-egalitaristiske værdier. Dette kan gøres ved at omfordele mellem dem, der løber ensartede risici men oplever vidt forskellige udfald.

Bert drøner ud af landevejen på sin motorcykel. Han elsker følelsen af fart og frihed. Han er vild med luft i både håret og budgettet, så han har hverken forsikring eller styrthjelm. Pludselig går det galt, Bert styrter og kommer slemt til skade. Uden styrthjelm og forsikring er situationen yderst alvorlig. Inden for den politiske teori påpeges det, at situationen også er alvorlig for den indflydelsesrige teori, held-egalitaristismen. Denne teoriretning betragter fordelingen af samfundets goder og byrder som retfærdig, når, og kun når, menneskers relative position afspejler deres udøvelse af ansvar. Det anføres, at held-egalitarismen må betegne den fremkomne fordeling som retfærdig og ikke kan retfærdiggøre at hjælpe Bert (Anderson, 1999: 296; Fleurbaey, 1995: 40). Artiklens formål er normativt at diskutere styrken af denne kritik og afklare, om held-egalitarismen med henvisning til egne værdier kan retfærdiggøre en sådan omfordeling. Artiklen konkluderer, at held-egalitarister både kan undgå at svigte folk som Bert og gøre dette uden at bryde med værdifulde friheder eller lade nogen bære omkostningerne for andres valg. ${ }^{1}$ Det vurderes, at særligt afgifter på risikofyldte aktiviteter afspejler de held-egalitaristiske værdier og gør det muligt at omfordele til dem, der gennem deres egne valg ender under et behovsminimum.

\section{Held-egalitarismen og det personlige ansvar i fordelingsmæssig retfærdighed}

Diskussionen om Bert og dem, der gennem egne valg ender under et behovsminimum, fortsætter en længere debat om, hvorledes individuelle valg påvirker fordelingers retfærdighed. Denne opstod i den revitalisering af normativ 
politisk teori, der fulgte udgivelsen af John Rawls' En teori om retfardighed. Rawls argumenterer for, at det er uretfærdigt at lade fordelinger være præget af naturlige eller sociale omstændigheder, fordi sådanne omstændigheder er uvalgte og arbitrære (Rawls, 1971: 72). Rawls argumenterer for et differensprincip, der tilsiger, at uligheder kun kan retfærdiggøres, hvis de er til gavn for de dårligst stillede. Held-egalitarismen ønsker i lighed med Rawls at udligne forskelle, der skyldes uvalgte omstændigheder. Men uligheder opstår også som følge af folks valg. I synet på sådanne uligheder korrigerer held-egalitarismen det, nogen betragter som en alvorlig mangel i Rawls' teoridannelse (Knight og Stemplowska, 2011: 4; Segall, 2010: 10). Differensprincippet kan sagtens kræve omfordeling til folk, der er dårligst stillet som følge af deres egne valg og præferencer (Kymlicka, 2002: 73-76). Det betyder, at der omfordeles for at finansiere, at nogen har valgt at leve med en bestemt livsstil og efter bestemte værdier, fra folk, der ikke deler dette mere ressourcekrævende syn på livet og afstår fra at leve således. Held-egalitarismen opstår dermed i en dialektisk kontekst, hvor udgangspunktet er Rawls' manglende håndtering af individers valg.

Teoriretningen opstår også som modsvar på en central højrekritik af den klassiske egalitarisme, der foretrækker, at alle mennesker skal have det samme. Højrekritikken påpeger, at dette lighedsideal omfordeler således, at menneskers forskelligartede præferencer for, hvor meget de vil arbejde, hvor forsigtige eller hvor sparsommelige de er, ikke får lov at influere den endelige fordeling (Nozick, 1974: 161-162). Held-egalitarismen rammes ikke af denne kritik og deler dens intuitioner. Det udtrykkes således af G.A. Cohen: "Hvorfor skulle de... der træffer forskellige valg fra et udgangspunkt med lige muligheder tvinges tilbage til lighed, hvis der opstår ulighed? Hvorfor skal en person betale for en andens valg?” (2006: 6).

Det er bemærkelsesværdigt, at held-egalitarismens ønske om ikke at lade nogen betale for andres valg er centralt både i dens relation til Rawls-litteraturen og til højreliberalismen. Held-egalitarismen indebærer et ønske om at holde mennesker ansvarlige for deres valg og kompensere dem for uvalgte omstændigheder. Dermed bliver den et vigtigt bidrag til debatten om individers valg og ansvar (Kymlicka, 2006: 17; Roemer, 1996: 164, 237).

Ofte operationaliseres held-egalitarismen ved Ronald Dworkins klassiske distinktion mellem option luck og brute luck. Førstnævnte beskriver udfaldet af bevidste sats, en person havde kontrol over samt mulighed for at afvise, mens sidstnævnte beskriver tilfælde af held, der ikke har en sådan karakter (Brown, 2009: 59; Dworkin, 2000: 73; Rakowski, 1991: 73). Held-egalitarismen udligner de forskelle, der følger af brute luck, men ikke dem, der følger af option luck (Rakowski, 1991: 75). I lyset af denne distinktion bør Bert betragtes som 
en person, der grundet dårlig option luck er voldsomt ringere stillet end andre (Anderson, 1999: 296; Fleurbaey, 1995: 40). Det relevante spørgsmål er, om held-egalitarismen er ubarmhjertig, fordi den må betragte sådanne situationer som retfærdige og ikke kan retfærdiggøre omfordeling. Denne artikel diskuterer, hvorfra ubarmhjertighedsindvendingen får sin styrke, og vurderer, hvorledes held-egalitarismen kan undgå denne "ubarmhjertighedsindvending", ved at efterprøve, om held-egaltarismen på egne præmisser og med baggrund i egne værdier er i stand til at retfærdiggøre omfordeling til dem, der rammes hårdt af dårlig option luck. Denne udlægning af problemstillingen indeholder et vigtigt fravalg. I artiklen undersøges det ikke, hvorvidt held-egalitarismen ved på pluralistisk vis at appellere til andre værdier (fx solidaritet) kan retfærdigøre omfordeling. Spørgsmålet er dermed ikke, om held-egalitarister kan sige, at de alt andet lige foretrækker omfordelingen. Derimod er spørgsmålet, om held-egalitarismen, i sig selv og ved at appellere til egne iboende værdier, kan modstå den indvending, der af mange betragtes som den mest centrale imod denne teori om fordelingsmæssig retfærdighed. Denne sidste tilgang til problemstillingen vælges primært, fordi det synes væsentligere at klargøre, hvorvidt held-egalitarismen i sig selv kan imødegå kritikken. Artiklens metodologiske tilgang er politisk teoretisk i den forstand, at diskussionen søger at afklare, hvorledes noget $b ø r$ være. Dette gøres ved konceptuelt at afklare centrale værdiers indhold (Holtug, 2010), særligt i relation til de værdier der synes at komme i konflikt i eksemplet med Bert. I den forbindelse diskuteres, hvordan og hvornår disse værdier kommer i konflikt med hinanden, og dermed hvilke implikationer det har at vælge nogle værdier frem for andre. Efter diskussionen om hvorledes værdierne er i konflikt med hinanden, og hvordan denne konflikt er potentielt problematisk for held-egalitarismen, undersøges det, hvorvidt det er muligt at justere værdierne, så de får en udformning, der mindsker eller fjerner graden af konflikt og dermed udgør et held-egalitaristisk svar på ubarmhjertighedsindvendingen. Tilgangen er således meget lig det, der betegnes refleksiv ligevægt. Artiklen leverer herigennem to distinkte bidrag. Dels bidrager den til en normativ diskussion af en central indvending mod held-egalitarismen ved at diskutere udformningen tilgangens grundlæggende værdier. Dels diskuterer den, i et anvendt etisk perspektiv, hvilke konkrete tiltag der kunne imødegå indvendingen og bevæge et samfund tættere på at indfri held-egalitaristiske værdier.

\section{Ubarmhjertighedsindvendingen og dens styrke}

Ubarmhjertighedsindvendingens styrke fremkommer, fordi det synes bydende nødvendigt, at en teori om den retfærdige fordeling af samfundets goder kan 
retfærdiggøre hjælp til mennesker med enorme lidelser. Indvendingen fremhæver ifølge Andrew Williams en potentiel konflikt mellem hensynet til tre meget stærke værdier: tilstrækkelighed, frihed og at mennesker ikke skal finansiere de udgifter, der følger af andres valg. Tilstrækkelighedsværdien handler om, at ingen bør leve under et minimum, hvor basale behov ikke opfyldes. Det er ikke relevant, hvor eller hvordan dette basale minimum kan fastsættes, men det synes plausibelt, at der findes en nedre grænse, hvor få ressourcer og/eller store lidelser forhindrer et menneske i at fungere, og at vi bør bekymre os om, at mennesker falder under dette minimum. Den efterfølgende diskussion vil være foreneligt med flere forskellige specifikationer af dette hensyn. Hensynet til denne værdi vil i det følgende blive omtalt som tilstrakkelighedshensynet. Den anden værdi er den individuelle frihed. Det er friheden til at kunne leve et liv i overensstemmelse med egne værdier, ønsker og prioriteringer. Den aktualiseres af ubarmhjertighedsindvendingen, fordi Bert ender langt værre end andre på grund af sine egne frie og frivillige handlinger. Det udtrykkes af Williams som en meget bred frihed til at gøre, som man ønsker. Hensynet til denne værdi vil blive omtalt som frihedshensynet. Den tredje værdi handler om ikke at lade personer hæfte for de udgifter, der skabes af andre. Det grundlæggende heri er, at ingen mennesker, der gennem sine valg skaber et større ressourcebehov for dem selv, skal have ret til kompensation fra andre. Dette vedrører både udgifter, der opstår, fordi nogen udvikler ekstravagante behov eller formøbler deres tildelte ressourceandel. Sådanne forskelle skal ikke udlignes, og de udgifter, der opstår på denne måde, skal finansieres af dem, der har truffet sådanne valg. Hensynet hertil vil blive omtalt som finansieringshensynet. ${ }^{3}$

Ifølge Andrew Williams illustrerer eksemplet med Bert, at konflikten imellem disse hensyn er et såkaldt trilemma, hvor vi ikke kan agere således, at alle tre værdier respekteres samtidig (Willams, 2006: 502). Hvis vi lader Bert dø/ lide, lader vi ham falde under et basalt minimum; hvis vi hjælper ham, lader vi andre bære omkostningerne for de valg, han har truffet; og hvis vi forhindrer ham i at handle, som han gør, begrænser vi hans frihed. Ifølge Williams kan vi analytisk skelne mellem to måder at sikre, at ingen rammes så hårdt af option luck, at de falder under et minimum af basale behov. Enten imødekommes tilstrækkelighedshensynet på en måde, der undgår, at finansieringshensynet tilsidesættes, ved at internalisere byrder eller begrænsninger, så de pålægges den, der har valgt at handle på en måde, der skaber udgifter. Ifølge Williams er det denne form for løsning, der anvendes, når folk tvinges til at forsikre sig, eller risikofyldte aktiviteter pålægges afgifter eller direkte forbydes. Alternativer hertil er at eksternalisere omkostningerne. Dette indebærer at tillade, at omkostningerne for nogle menneskers handlinger væltes over på andre, men ikke 
at frihedshensynet tilsidesættes (Williams, 2006: 501-502). Williams betegner en generel beskatning som et eksempel på eksternalisering af omkostningerne. Begge måder at imødekomme tilstrækkelighedshensynet på er problematiske for held-egalitarismen, der i sine klassiske formuleringer indeholder en tilslutning til både friheds- og finansieringshensynet.

\section{Et initialt modsvar fra held-egalitarismen}

Det er dog indledningsvis nødvendigt med nogle præciseringer. Nogle har argumenteret for, at held-egalitarismen kun virker ubarmhjertig, fordi kritikerne ikke formår at adskille brute luck fra option luck. Brute luck påvirker folks valg og dermed deres option luck. Brute luck kan både påvirke vores evne til at træffe valg (Kauffmann, 2004: 822), vores præferencer (Cohen, 1989: 922) eller de tilstedeværende valgmuligheder. Pointen er, at held-egalitarismen ikke opfatter det som retfærdigt at lade folk bære konsekvenserne af deres valg, når disse i praksis er påvirket af brute luck (Barry, 2005; Barry, 2006; Voigt, 2007: 395). Det ville i eksemplet med Bert betyde, at vi kunne kompensere ham, hvis hans valg var påvirket af hans sociale ophav. Dette er dog ikke tilstrækkeligt til at afvise ubarmhjertighedsindvendingen, fordi der stadig kan tænkes teoretiske som virkelige eksempler, hvor den vil være relevant. Kristine Voight har tydeliggjort dette ved at formulere en kvalificeret ubarmhjertighedsindvending, der tager hensyn til de her nævnte forhold: "Når en person ender med at være meget ringe stillet som følge af ren 'option luck' - dvs. når ulige brute luck ikke påvirkede det valg, personen stod overfor ... og når personen ikke valgte at udøve det ansvar, vi med rimelighed kunne forvente af vedkommende (justeret i forhold til relevant brute luck), så kræver held-egalitarismen. at vi ikke hjælper personen ..." (Voight, 2007: 402).

Selvom der er (mange) tilfælde, hvor påvirkningen fra brute luck gør, at det ikke er åbenlyst, om en person bør kompenseres, så er der også eksempler på det modsatte. Det synes rimeligt at tale om, at en person udsættes for dårlig option luck, hvis han i høj fart og uden sikkerhedssele forulykker på en øde vej i godt føre. Et sådant valg indebærer en risiko, og han ender ringere stillet end andre som en konsekvens af sit valg. Tilsvarende må det siges, at forskellen mellem to personer, der på ensartet måde påvirkes af brute luck men træffer forskellige valg, er udtryk for option luck. Held-egalitarismen ikke er forpligtet til at lade mennesker bære konsekvenserne af valg, der er influeret af brute luck, men dette er ikke tilstrækkeligt til at afvise ubarmhjertighedsindvendingen. Tilbage står diskussionen om, hvorvidt held-egalitarismen, i et samfund der har elimineret indflydelsen fra brute luck, kan retfærdiggøre at hjælpe dem, der rammes hårdt af dårlig option luck. 
Inden denne diskussion tages, bør det nævnes, at Zofia Stemploska har argumenteret for, at det måske slet ikke er så uplausibelt, at Bert ikke modtager hjælp - og hun understreger, at det modsatte synspunkt, at vi altid skal hjælpe alle, der bliver dårligt stillet grundet deres egne valg, har stærkt uplausible konsekvenser. Stemplowska beskriver en uforsikret og uforberedt bjergbestiger, der gentagne gange tager ud for at bestige bjerge. Hvis denne person er velforvaret, forsikringer findes, og det er meget dyrt at redde ham med en helikopter - har han så virkelig krav på at blive reddet, hver gang behovet opstår? (Stemplowska, 2009: 252). ${ }^{4}$ Selvom dette muligvis kan være en udvej for held-egalitarismen, er det ikke et svar til dem, der opfatter held-egalitarismen som uattraktiv, fordi den har netop sådanne konsekvenser. I lyset af at mange med baggrund i argumentet om, at held-egalitarismen har sådanne konsekvenser, mener, at held-egalitarismen er en uplausibel og ikke attraktiv teori om fordelingsmæssig retfærdighed, synes det givtigt at undersøge, hvorvidt den faktisk har disse konsekvenser. Det vil derfor blive afklaret, om held-egalitarismen med henvisning til egne præmisser kan imødegå ubarmhjertighedsindvendingen uden at lede til konklusioner, som de, der fremfører ubarmhjertighedsindvendingen, ikke kan acceptere.

\section{Held-egalitaristiske muligheder for at undgå ubarmhjertighedsindvendingen}

Efter en afklaring af indvendingens indhold og en vurdering af umiddelbare løsninger vil andre forslag til, hvorledes held-egalitarismen kan imødekomme tilstrækkelighedshensynet, blive diskuteret. Indledningsvis vurderes eksternaliseringsstrategien gennem en diskussion af modellen, hvor udgifterne finansieres gennem en generel skat. Herefter vurderes forskellige versioner af de internaliserende forsøg på at sikre tilstrækkelighedshensynet, hvor det konkluderes, at det er frugtbart at imødekomme dette gennem afgifter på risikofyldte aktiviteter og tvungne forsikringsordninger. Førstnævnte løsningsmodel har dog væsentlige fordele, og derfor vil den være genstand for en afrundende drøftelse.

\section{Eksternaliseringsstrategi}

Et skattefinansieret sundhedsvæsen kan garantere, at ingen, uanset deres egne valg, lever under et basalt behovsminimum. Sådan en finansieringsform kendes fra mange vesteuropæiske lande (Doorslaer et al., 1993). Lad os derfor betragte de normative perspektiver ved en finansieringsform, der tager goder fra samfundets borgere som helhed og bruger disse til at sikre hjælp til alle. Denne finansieringsform er i stand til at imødekomme tilstrækkelighedshensynet og frihedshensynet, men til gengæld er det et klart brud på finansieringshensynet, 
at folks bidrag er uafhængigt af, hvorledes de selv har handlet. Det bør på ny betones, at dette hensyn er vigtigt for flere held-egalitarister, fordi det forhindrer, at nogen i en situation med lige muligheder kan træffe valg, der leder til, at andre skal kompensere dem. Pointen er, at sådanne kompensationer mindsker ressourcemængden til rådighed for alle dem, der ikke handlede således. Når nogen har udgifter, der opstår, fordi de lever livet på en bestemt måde, så er det ikke retfærdigt at bede alle dem, der ikke valgte således, om at finansiere disse udgifter. Ovenstående udgør en principiel afvisning af den generelle skattefinansiering som en løsning på trilemmaet. Når forskellene i brute luck er udlignet (eksempelvis gennem skattefinansiering), så er det ikke retfærdigt at lave yderligere generelle omfordelinger for at udligne forskelle i option luck.

\section{Internaliseringsløsninger}

I det følgende vil de løsninger blive diskuteret, der sikrer, at ingen falder under et behovsminimum ved at begrænse friheden for den enkelte, men uden at lade andre betale for de udgifter, en person skaber ved sine handlinger. Det betyder, at tiltag som forbud og tvungne forsikringer vil blive vurderet på, hvorvidt de løser trilemmaet på en hensigtsmæssig måde.

\section{Forbudsløsninger}

Det mest vidtgående tiltag er at forbyde alle handlinger, der indeholder en risiko for, at en person ender under det basale minimum. Dette er en klassisk paternalistisk tilgang, hvor menneskers frihed begrænses ud fra et hensyn til dem selv. Tankegangen kendes i mildere grad fra forbud mod at køre bil uden sikkerhedssele eller motorcykel uden hjelm. Forbuddene gennemføres, for at ingen skal handle således, at de ender med at komme meget alvorligt til skade. Det synes at være en uattraktiv løsning på ubarmhjertighedsindvendingen. Det skyldes, at det vil kræve et meget stort antal forbud at realisere denne løsning. Folk kan komme slemt til skade på cykel, på den byggeplads hvor de arbejder, eller mens de reparerer noget på deres eget tag. Det kræver derfor et enormt indgreb i folks frihed at forbyde alle de aktiviteter, der indebærer en risiko for, at de kommer til skade i en grad, der sender dem under et basalt minimum. Dette store indgreb i friheden gør, at en forbudsstrategi ikke er en attraktiv løsning. Den sikrer, hvis forbuddet følges, på behørig vis hensynet til tilstrakkelighed og finansiering, men indeholder et meget omfattende indgreb i den frihed, held-egalitarister også værdsætter.

Det synes dog umiddelbart muligt at opnå et tilsvarende resultat ved et mindre omfattende indgreb i friheden. Dette kan gøres ved at indføre tvungne forsikringsordninger for alle. Her tvinges alle til at indbetale en forsikrings- 
præmie og dækkes i tilfælde af uheld. Herved fratages folk friheden til at leve livet uden forsikring. Sådanne tvungne individuelle forsikringer respekterer finansieringshensynet og tilstrækkelighedshensynet, men tillader umiddelbart brud på friheden. Derfor synes den tvungne forsikringsordning, fordi bruddet på friheden er mindre, at være mere attraktiv end den meget omfattende forbudsløsning, men stadig et brud på friheden.

I modsætning til ovenstående har Poul Bou-Habib argumenteret for, at de tvungne forsikringer er en fuldgyldig løsning på trilemmaet (Bou-Habib, 2006: 248). Han mener, at de tvungne forsikringer kan begrundes uden at henvise til et paternalistisk hensyn til dem, der ellers ville komme til skade som følge af risikable valg. Bou-Habib begrunder i stedet den tvungne forsikringsordning med et hensyn til dem, der ikke træffer sådanne valg. Ifølge Bou-Habib vil der uden tvungne forsikringer opstå omkostninger for dem, der ikke træffer risikable valg. De vil føle en forpligtelse over for dem, der lider, uanset persoligt ansvar. At opfylde denne pligt har økonomiske omkostninger - ligesom det at have viden om, at man hvert øjeblik kan risikere at skulle dække omkostningerne for andres handlinger også er en slags omkostning (Bou-habib, 2006: 248, 251). Tvungne forsikringer befrier dem, der ikke tager de store risici, for sådanne omkostninger. Ifølge Bou-Habib er tvungne forsikringer, der indføres af ikke-paternalistiske årsager, en løsning på trilemmaet. Det er tilfældet, fordi løsningen bringer den tilskadekomne op på et vist niveau, ikke lader andre hæfte for vedkommendes handlinger og ikke er paternalistisk (2006: 252).

Det er væsentligt, at Bou-Habibs beskrivelse af trilemmaets sidste element adskiller sig fra Willams' oprindelige trilemma, der havde frihed som den tredje værdi. ${ }^{5}$ Williams opererer med en bred forståelse af frihed, hvor det, uanset om disse indføres af paternalistiske eller ikke paternalistiske grunde, opfattes som frihedsbegrænsende at indføre tvungne forsikringer, forbud og afgifter (Williams, 2006: 502). Bou-Habibs løsning på trilemmaet sker dermed ved en ændring af forståelsen af frihed. Når det skal vurderes, hvorvidt held-egalitarister kan anvende Bou-Habibs forslag til, hvorledes ubarmhjertighedsindvendingen kan imødegås, er det vigtige, om den frihedsforståelse, han bringer i anvendelse, er i overensstemmelse med held-egalitarismen. Det afgørende i denne diskussion er dermed, om ændringen til et smallere frihedsbegreb synes i overensstemmelse med held-egalitaristiske værdier.

Helt overordnet synes der at være gode grunde til, at held-egalitarister ikke kan tilslutte sig en bred frihedsopfattelse, hvor alle begrænsninger af friheden er problematiske. Det skyldes, at et så bredt frihedsbegreb vil betegne det som problematisk at omfordele for at kompensere mennesker for dårlig brute luck. En sådan omfordeling er helt central for held-egalitarister af enhver støbning. 
Der synes i første omgang ikke at være grunde til, at held-egalitarister skulle være tilhængere af denne meget brede forståelse af frihed. Det næste, der bør overvejes, er, om den frihed, skiftet fra en bred til en smal frihedsforståelse fratager folk, er vigtig. Er friheden til at leve farligt og uforsikret en central del af den frihed, held-egalitarister hylder? Begrundelsen for at afvise dette kunne være, at vi med udgangspunkt i finansieringshensynet og tilstrækkelighedshensyn kan argumentere for, at der er bestemte typer friheder, der ikke er lige så vigtige og tungtvejende som disse hensyn. Fra et held-egalitaristisk perspektiv er det umiddelbart en attraktiv tilgang til trilemmaet at ændre synet på friheden i den retning, Bou-Habib foreslår. Mennesker bevarer en stor del af deres frihed, de efterlades ikke til de rå konsekvenser af deres egne valg, og den frihed, de mister, er friheden til at vælte omkostningerne fra valg over på andre - en frihed der i et held-egalitaristisk perspektiv ikke kan være vigtig, idet den er i direkte konflikt med det held-egalitaristiske finansieringshensyn og behovet for at omfordele til dem, der rammes af brute luck.

Alligevel synes denne ændring af frihedsopfattelsen at være utilstrækkelig til helt at afværge ubarmhjertighedsindvendingen. I hvert fald vil en kollektiv forsikringsordning med ensartede præmier for alle i høj grad have samme konsekvens som en skattefinansieret universel ordning. Ved kollektive forsikringsordninger, der gælder alle og har ens præmier for alle, betaler både de, der ikke træffer risikofyldte valg, og de, der traf risikofyldte valg, der ikke medførte udgifter til at dække udgifterne. Dette er på problematisk vis i strid med held-egalitarismens finansieringshensyn. Forsikringsløsningen synes derfor tættest på at løse ubarmhjertighedsindvendingen, hvis der er tale om, at forsikringspræmien varierer med individers adfærd. Det er tilfældet, fordi det ved individuelle forsikringsordninger vil være lettere at justere præmien opad hos personer, der tidligere har udvist stor risikofyldt adfærd. En løsning synes at være, at forsikringspræmierne i højere grad individualiseres, så de varierer efter, hvorledes folk tidligere har opført sig. Det korrigerer det netop omtalte problem, men skaber samtidig et nyt, som går på, at en forsikringsløsning, hvor det fx er dyrere for rygere end ikke-rygere at forsikre sig, har en alvorlig mangel. Nok sørger denne indretning for, at ikke-rygere slipper for at betale for de udgifter, ryger skaber, men den medfører også, at der internt blandt rygere sker en omfordeling, hvor de, der ikke bliver syge, er med til at betale for dem, der gør. Det er derfor uklart, hvorvidt det ændrede syn på friheden, hvor friheden til ved at leve livet uforsikret at gøre indhug i andres ressourcer ikke regnes for vigtig, er tilstrækkelig som løsning på trilemmaet. De tvungne forsikringsordninger med individualiserede præmier synes ikke i første omgang at kunne levere en helstøbt løsning på ubarmhjertighedsindvendingen. 


\section{Afgiftslosninger}

Dette afsnit diskuterer en anden af de løsninger, Williams betegner som internaliserende løsninger. Det er den type løsninger, der indebærer, at risikofyldte aktiviteter pålægges en afgift. Løsningen minder om den, man i økonomien kender fra eksternaliteter. Her hvor temaet er handlinger med omkostninger for tredjepart, er der god ræson i at overveje at modvirke denne omvæltning af omkostninger ved at øge prisen på bestemte handlinger, således at den afspejler en funktion af risikoens sandsynlighed og pris. Det vil betyde afgifter på cigaretter, fed mad og særligt risikofyldte aktiviteter. Denne finansieringsform er temmelig udbredt og kaldes i Belgien for "syndeskatter" (Mossialos og Le Grand, 1999: 5). Williams betegner denne strategi som en internaliserende måde at sikre tilstrækkeligheden på, fordi den lader dem, der løber risikoen, dække de udgifter, deres handlinger skaber.

Der synes dog at være grund til at overveje holdbarheden af denne klassificering. Synde-skatter sikrer nok, at ingen falder under det basale minimum, men det kan betvivles, om det lykkes at internalisere omkostningerne. Betragt en gruppe mennesker, der løber en risiko og af denne grund pålægges en afgift. Det er langt fra givet, at alle de menneskers risikofyldte adfærd resulterer i udgifter. Idet personer også betaler afgiften, når deres handlinger ikke skaber udgifter, hæfter nogen stadig for de udgifter, andre skaber. Dette indebærer et mindre brud på finansieringsværdien end ved den kollektive forsikringsordning, men stadig et brud. På denne måde er der ligheder med de individuelle forsikringsordninger. I afgiftsdiskussionen betaler ikke-rygere ikke til rygeres sygdom, men de mennesker, hvis rygning ikke resulterede i sygdom, betaler til dem, der blev syge af deres rygning (og antageligt fik et liv under et basalt minimum). Afgifterne isolerer udgifterne som et anliggende for dem, der agerer risikofyldt men indebærer alligevel, at de, der løb en risiko, der ikke medførte en udgift, betaler til dem, hvis risikofyldte adfærd skabte en udgift. I lighed med den tidligere diskussion, hvor det blev vurderet rimeligt at justere frihedshensynet på en måde, hvor friheden til at leve livet uforsikret ikke er en central frihed, er det her værd at overveje, om ovenstående bør give anledning til en justering af finansieringshensynet.

I den forbindelse er det nærliggende at inddrage en version af held-egalitarismen, der giver en anden fortolkning af, hvem det er rimeligt at bede om at finansiere udgifterne til dem, der rammes af dårlig option luck. Den tilgang - all luck egalitarianism - der vil blive diskuteret i det følgende, deler held-egalitarismens intuitioner, men mener, at disse er dårligt afspejlet i den klassiske Dworkin-inspirerede version, hvor forskelle i option luck ik ke berettiger kompensation, mens forskelle i brute luck gør. All luck-egalitaristerne mener i ste- 
det, at også forskelle i option luck på relevant vis udgør en forskel i held (Barry, 2008: 137; Capellen og Nordheim, 2005, 2006; Cohen, 2009: 9; Lippert-Rasmussen, 2005: 367, 375, 385). De er derfor tilhængere af også på relevant vis at udjævne forskelle i option luck. Når mennesker fra et lige udgangspunkt løber samme risiko, er det et udtryk for forskel i held, om deres option luck er god eller dårlig. Argumentet er, at folk vælger deres gambles, men ikke udfaldene af dem. Forskelle, der opstår på denne måde, er det ifølge fortalere for all luckegalitarianisme ikke forkert at udligne gennem omfordeling.

Målsætningen er, at mennesker, der løb lige store risici, skal ende samme sted, men at mennesker, der løb forskellige risici, gerne må ende i ulige positioner, der svarer til den udøvede grad af ansvar. Dette er, selv blandt held-egalitarister, en kontroversiel position, der derfor kræver uddybende begrundelse. Rationalet bag dette ændrede syn på option luck er, at sådanne uligheder adskiller sig fra situationer, hvor mennesker frivilligt vælger at være dårligere stillet end andre, fordi det, individerne i denne situation valgte, blot var at udsætte sig selv for en risiko (Barry, 2008: 137; Lippert-Rasmussen, 2005: 382). Denne position kan underbygges med et eksempel (jf. Lippert-Rasmussen, 2005: 385). Betragt to personer, der begge kan vælge et af følgende væddemål:

1: 100 pct. chance for at modtage $100 \mathrm{kr}$.

2: 95 pct. chance for at modtage $100 \mathrm{kr}$. og 5 pct. chance for at modtage $200 \mathrm{kr}$.

Fuldt forståeligt vælger de begge væddemål nr. 2, men den ene ender med 100, og den anden med 200. Forskellene mellem dem er option luck, men det er også tilfældet, at den ene er ringere stillet end den anden uden selv at være skyld i det. Ovenstående overvejelser giver umiddelbart grund til at justere finansieringshensynet således, at det tillader omfordelinger, der udligner uligheder, der følger af option luck. Men sådanne omfordelinger bør forholde sig til Dworkins primære argument imod at omfordele forskelle, der opstår som følge af option luck. Denne modstand beror på hans grundlæggende ønske om at afsætte lige mange ressourcer til hvert enkelt liv. Dworkin argumenterer for, at dette princip brydes, hvis vi omfordeler fra vindere til tabere af et gamble, fordi vi derved fratager nogle individer muligheden for at leve et liv med risikabel adfærd (Dworkin, 2000: 74-75). Med en central distinktion gør Lippert-Rasmussen det muligt at afvise dette forsvar. Han siger, vi kan skelne mellem egentlige gambles og quasi-gambles. Sidstnævnte er situationer, hvor personen ville vælge væddemålets forventede værdi frem for selve væddemålet og den dertil hørende risiko for, at det falder bedre eller dårligere ud 
end forventet. Egentlige væddemål er de tilfælde, vi kender fra kasinoet eller travbanen, hvor risikoen er en del af formålet, og ingen af de deltagende ville foretrække den forventede værdi (Lippert-Rasmussen, 2005: 363). Argumentet imod omfordeling mellem gamblernes vindere og tabere synes intuitivt stærkt, når det anvendes på egentlige gambles, men tilsvarende uplausibelt at anvende på quasi-gambles. I sidstnævnte tilfælde fratages ingen deres ønske om at leve et bestemt liv, men derimod pooles og minimeres en risiko, som de berørte helst vil være foruden. De befries dermed for en risiko, de helst ville undvære. Et er selvsagt, om selve distinktionen er teoretisk frugtbar, noget andet er, om de valg, mennesker træffer, der kan føre dem ned under et bestemt behovsminimum, bør klassificeres som quasi-gambles eller egentlige gambles. Kun hvis de kan klassificeres som førstnævnte, er det en mulighed at omfordele mellem vindere og tabere.

Segall anfører, at tilfælde som rygning blandt unge og ekstremsport er egentlige gambles, fordi de udføres for spændingens skyld (Segall, 2010: 50). Det ville betyde, at all luck egalitarianism ikke kan forsvare at omfordele mellem dem, der tager sådanne. Men Segalls argument beror på en forvrængning af, hvornår noget er et egentligt gamble. For det er plausibelt, at både rygning blandt unge og faldskærmsudspring gøres for spændingens skyld. Men denne spænding kan også fremkomme fra det forbudte, følelsen af at gøre noget anderledes eller de rent fysiske processer, der er på spil - og dermed ikke fra selve risikoen for at komme til skade. Lakmusprøven på, om det er et egentligt gamble, er, om man ville foretrække den forventede værdi og undvære risikoen. Det synes at være en korrekt beskrivelse af også sådanne aktiviteter. Hvis vi reducerede eller fjernede de skadelige stoffer i alle cigaretter, synes det uplausibelt, at det, at det ikke længere er farligt, ville reducere eller afskaffe rygning blandt unge. Hvis det er rimeligt at antage, at den forventede værdi af rygning er luftvejsgener og ringere kondi (men altså ikke lungekræft), så synes skellet mellem egentlige gambles og quasi-gambles succesfuldt at kunne anvendes til at forsvare en omfordeling fra dem, der med held udsætter deres helbred for et quasigamble, til dem, der taber et tilsvarende gamble. Det næste relevante spørgsmål er så, hvorvidt det med rimelighed kan siges, at argumentet fra rygning kan generaliseres, eller rettere om der kan påpeges tilfælde af egentlige gambles, hvor folk ender under et basalt minimum. I de hidtil nævnte eksempler på tilfælde, der bringer folk under et egentligt minimum synes det åbenlyst, at folk helst ville undvære spændingen og foretrække den forventede værdi af deres gambles. Ingen cykler på arbejde, reparerer taget på deres hus eller kører uden sikkerhedssele for spændingens skyld, og risikoen synes bestemt ikke at være en del af formålet. Men det er vel muligt at indgå egentlige gambles, der sender en 
under et behovsminimum? To personer kunne vædde om, hvem der skulle være den andens slave, eller en person kunne smide hele formuen på en rød 7’er på rouletten og tabe alt. Disse tilfælde kan teoretisk tænkes. Men det er svært at forestille sig dem blive til virkelighed uden en kraftig påvirkning af brute luck. I langt hovedparten af tænkelige cases er den form for gamble, der er til stede, quasi-gambles, og derfor tillader det justerede syn på option luck omfordeling.

Ovenstående udgør to distinkte men vigtige skridt i retning af en accept af all luck egalitarianisme som et plausibelt svar på ubarmhjertighedsindvendingen. Dels er der blevet argumenteret for, at denne justering af, hvilke uligheder held egalitarismen tillader, er konceptuelt meningsfuld, og det er søgt at sandsynliggøre, at den også er normativt attraktiv. Det sidste blev gjort på to måder. Dels ved at henvise til cases hvor omfordeling af forskelle grundet option luck synes rimelig, dels ved at introducere skellet mellem quasi og proper gambles. Afslutningsvis blev der argumenteret for, at det netop er quasi-gambles, der er på spil i ubarmhjertighedsindvendingen. Tilbage står et brugbart princip om, at retfærdigheden tilskynder os til at udligne fordelinger, der ikke afspejler menneskers valg. Når mennesker træffer forskellige valg, må det gerne lede til forskelle, men når de vælger ens og tager gambles, hvor de ville foretrække den forventede risiko, så er det retfærdigt, at de, der risikerer at påføre andre udgifter, skal bidrage til de udgifter, der kausalt skabes af andre, der handler som dem, i tilfælde hvor deres egne handlinger ikke medførte sådanne udgifter. Et eksempel på appliceringen af denne tankegang er mennesker, der kører bil, mens de er fulde. De, der i fuldskab kører galt og forvolder materiel og/eller personskade, skaber ved deres handlinger en udgift. De mennesker, der kører bil i fuldskab men ikke rammer nogen, har handlet lige så uansvarligt og med lige så stor mulighed for at skabe udgifter for andre. Så når folk tages i at køre spirituskørsel på en i øvrigt øde vej, så bør bøden afspejle det forhold, at de med deres adfærd risikerede at skabe udgifter for andre. Det giver dermed grunde til at omfordele internt mellem alle dem, der løb den samme risiko, og hvor forskellen dermed i relevant forstand er et udtryk for held (Barry, 2008: 144).

Ovenstående diskussion af all luck egalitarianism bidrager til diskussionen af muligheden for at finansiere, at tilstrækkelighedshensynet bliver tilgodeset via afgifter på risikofyldt adfærd. Det ændrede syn på option luck betyder ikke, at det bliver retfærdigt at udligne eventuelle forskelle mellem dem, der valgte at udsætte sig selv for risikoen for at blive ramt af dårlig option luck ved at indgå i quasi gambles, og dem, der ikke gjorde. Hvis denne mere plausible forståelse af, hvornår det er tilladeligt at lade folk hæfte for noget, anvendes, så udgør afgifterne en stærk afvisning af ubarmhjertighedsindvendingen, der ikke bryder med trilemmaets værdier. Det involverer ingen forbud, og det sikres at ingen 
tvinges til at betale for udgifter, som de ikke selv ved deres handlinger risikerede at skabe.

\section{Konklusion}

I lyset af ovenstående diskussion synes ubarmhjertighedsindvendingen langt mindre kraftfuld end de, der fremfører den, giver udtryk for. Diskussionen af både afgiftsløsningen og løsningen med tvungne forsikringer viste, at det på flere måder er muligt for held-egalitarismen at bifalde omfordeling til dem, der rammes hårdt af option luck. I begge tilfælde kræver det en justering af vores forståelse af centrale held-egalitaristiske hensyn. Det kan konkluderes, at heldegalitarister godt kan tilslutte sig et justeret syn på friheden, der ikke inkluderer friheden til at leve livet uforsikret. Men denne løsning indebærer, at nogen kan komme til at betale for udgifter, som deres risikofyldte handlinger ikke skabte. Derfor synes det nødvendigt og rimeligt, at held-egalitarister justerer finansieringshensynet således, at det tillader omfordeling mellem mennesker, der udøver ensartet risikofyldt adfærd, selvom adfærden ikke i alle tilfælde medfører udgifter. Sådan adfærd kan rimeligvis beskattes gennem afgifter. På denne måde kan det konkluderes, at det er muligt med henvisning til heldegalitarismens egne iboende værdier at afvise ubarmhjertighedsindvendingen.

\section{Noter}

1. Der er variationer over, hvor meget dette princip fylder i litteraturen, men det er tydeligt hos eksempelvis Cohen, Dworkin og Rakowski.

2. Oversat fra "the harshness objection".

3. Der er variationer over, hvor meget dette princip fylder i litteraturen, men det er tydeligt hos Dworkin og Rakowski.

4. Tak til Kasper Lippert-Rasmussen, der foreslog også at inkludere dette perspektiv.

5. Dette er en væsensforskel, som Bou-Habib ikke forholder sig til (Bou-Habib, 2006: 244).

\section{Litteratur}

Anderson, Elizabeth S. (1999). What is the Point of Equality? Ethics 109 (2): 287-337. Barry, Brian (2005). Why Social Justice Matters. Cambridge: Polity.

Barry, Nicholas (2006). Defending Luck Egalitarianism. Journal of Applied Philosophy 23: 89-107.

Barry, Nicholas (2008). Reassessing Luck Egalitarianism. The Journal of Politics 70 (1): 136-150.

Bou-Habib, Paul (2006). Compulsory Insurance without Paternalism. Utilitas 18 (3): 243-263. 
Brown, Alexander (2009). Ronald Dworkin's Theory of Equality: Domestic and Global Perspectives. Basingstoke: Palgrave Macmillan.

Cappelen, Alexander W. og Ole F. Norheim (2005). Responsibility in Health Care: a Liberal Egalitarian Approach. Journal of Medical Ethics 31: 476-480.

Cappelen, Alexander W. og Ole F. Norheim (2006). Responsibility, Fairness and Rationing in Health Care. Health Policy 76 (3): 312-319.

Cohen, G.A. (1989). On the Currency of Egalitarian Justice. Ethics 99 (4): 906-944.

Cohen, G.A. (2006). Luck and Equality. Philosophy and Phenomenological Research 72 (2): $439-446$.

Cohen, G.A. (2009). Fairness and Legitimacy in Justice, and: Does Option Luck Ever Preserve Justice?, pp. 3-21 i Stephen de Wijze, Mathew H. Kramer og Ian Carter (red.), Hillel Steiner and the Anatomy of Justice: Themes and Challenges. New York: Routledge.

Doorslaer, Eddy, Adam Wagstaff og Frans Rutten (1993). Equity in the Finance and Delivery of Health Care: an International Perspective. New York: Oxford University Press.

Dworkin, Ronald (2000). Sovereign Virtue: the Theory and Practice of Equality. Cambridge, MA: Harvard University Press.

Fleurbaey, Marc (1995). Equal Opportunity or Equal Social Outcome? Economics and Philosophy 11 (01): 25-55.

Holtug, Nils (2010). Persons, Interests, and Justice. Oxford: Oxford University Press.

Kaufman, Alexander (2004). Choice, Responsibility and Equality. Political Studies 52: 819-836.

Knight, Carl og Zofia Stemplowska (2011). Responsibility and Redistribute Justice: An Introduction, pp. 1-24 i Carl Knight og Zofia Stemplowska (red.), Responsibility and Distributive Justice. Oxford: Oxford University Press.

Kymlicka, Will (2002). Contemporary Political Philosophy: An Introduction, 2. udg. Oxford: Oxford University Press.

Kymlicka, Will (2006). Left-Liberalism Revisited, pp. 9-35 i Christine Sypnowich (red.), The Egalitarian Conscience Essays in Honour of G.A. Cohen. Oxford: Oxford University Press.

Lippert-Rasmussen, Kasper (2005). Deontology, Responsibility, and Equality. København: Institut for Medier, Erkendelse of Formidling, Københavns Universitet.

Mossialos, Elias og Julian Le Grand (1999). Health Care and Cost Containment in the European Union. Aldershot: Brookfield.

Nozick, Robert (1974). Anarchy, State, and Utopia. Oxford: Blackwell.

Rakowski, Eric (1991). Equal Justice. Oxford: Clarendon.

Rawls, John (1971). A Theory of Justice. Cambridge, MA: Belknap Press. 
Roemer, John (1996). Theories of Distributive Justice. Cambridge, MA: Harvard University Press.

Segall, Shlomi (2010). Health, Luck, and Justice. Princeton, NJ: Princeton.

Stemplowska, Zofia (2009). Making Justice Sensitive to Responsibility. Political Studies 57 (2): 237-259.

Voigt, Kirstin (2007). The Harshness Objection: Is Luck Egalitarianism Too Harsh on the Victims of Option Luck? Ethical Theory and Moral Practice 10 (4): 389-407. Williams, Andrew (2006). Liberty, Equality and Property, pp. 488-506 i John Dryzek, Bonnie Honig og Anne Phillips (red.). The Oxford Handbook of Political Theory. Oxford: Oxford University Press. 